\title{
P05.21. Kangarooing in German neonatology departments: results of a nationwide survey
}

\author{
M Thiel ${ }^{1 *}$, A Längler ${ }^{1}$, T Ostermann $^{2}$ \\ From International Research Congress on Integrative Medicine and Health 2012 \\ Portland, Oregon, USA. 15-18 May 2012
}

\section{Purpose}

Kangaroo care is a technique practiced on newborn infants wherein the infant is held, skin-to-skin, with an adult. Our purpose was to assess practical aspects of performing kangaroo-care in German neonatal units.

\section{Methods}

A semi-structured questionnaire has been sent to all pediatric departments with neonatological units in Germany as published in the German hospital list and the German Society of Neonatology (GNPI). After 6 weeks a reminder was sent by e-mail.

\section{Results}

Of the 323 eligible neonatal care units, 162 (50.1\%) participated and 160 (98.8\%) reported using KC. Instructions for the staff are provided in 39 (25.2\%) units, 16 (10.3\%) for parents and 64 (41.4\%) have hygienical regulations for parents. Special chairs are provided in 143 (89.4\%) units, 29 (85.3\%) use music, 7 (20.6\%) light and 2 (5.9\%) aromatherapy as complementary methods. Fifty-one $(31.5 \%)$ provide security precautions, $22(26.8 \%)$ of them a transcutanous $\mathrm{O}_{2} / \mathrm{CO}_{2}$ probe, $15(18.3 \%)$ a limited number of infants at the same time, and $20(24.4 \%)$ require a physician in close distance. A certain gestational age in 146 units (91.25\%) and $142(88.7 \%)$ a certain bodyweight are considered as limits. One hundred thirty-eight (86.25\%) have a limitation of days of life before KC. In 63 (38.9\%) the gestational age and $69(42.6 \%)$ the birth weight had no influence on first KC. Fifty-two (32.1\%) use KC no matter of the infants' age. Thirty-five (21.6\%) departments have other preconditions, where cranial ultrasound is the most common $(\mathrm{n}=27,45 \%)$.

'Univ of Witten/Herdecke, Center Integrative Med, Dept of Pediatrics, Herdecke, Germany

Full list of author information is available at the end of the article

\section{Conclusion}

This is the first survey on practical aspects of kangaroocare in Germany. Most neonatal units provide hygienical regulations for staff and parents. Special equipment such as $\mathrm{KC}$-chairs is quite common as well as adding music as a complementary feature. Limitations regarding birth weight and gestational age are more common than other precautions. In conclusion the results could be helpful for clinical studies, especially to describe and compare the used setting or to design a joint concept if multicentre studies need comparable conditions.

\section{Author details}

'Univ of Witten/Herdecke, Center Integrative Med, Dept of Pediatrics, Herdecke, Germany. ${ }^{2}$ University of Witten/Herdecke, Faculty of Health, School of Medicine, Herdecke, Germany.

Published: 12 June 2012

doi:10.1186/1472-6882-12-S1-P381

Cite this article as: Thiel et al.: P05.21. Kangarooing in German

neonatology departments: results of a nationwide survey. $B M C$

Complementary and Alternative Medicine 2012 12(Suppl 1):P381.

Submit your next manuscript to BioMed Central and take full advantage of:

- Convenient online submission

- Thorough peer review

- No space constraints or color figure charges

- Immediate publication on acceptance

- Inclusion in PubMed, CAS, Scopus and Google Scholar

- Research which is freely available for redistribution

Submit your manuscript at www.biomedcentral.com/submit

\section{() Biomed Central}

C Biomed Central

C 2012 Thiel et al; licensee BioMed Central Ltd. This is an Open Access article distributed under the terms of the Creative Commons Attribution License (http://creativecommons.org/licenses/by/2.0), which permits unrestricted use, distribution, and reproduction in any medium, provided the original work is properly cited. 